\title{
Disappearing halophytes and saline habitats in changing environment of SW Slovakia
}

\author{
Alexander Fehér \\ Slovak University of Agriculture, Mariánska 10, 94901 Nitra, Slovakia \\ e-mail: sandfeher@gmail.com
}

\begin{abstract}
Summary. As a result of changes in land use, the ecologists and botanists already give details only of degradation, ruderalisation and fragmentation of halophytic plant communities (Camphorosmetum annuae, Limonio-Artemisietum santonici etc.) and the decline of halophytes on those sites (missing grazing, ploughing away, hydro-amelioration etc.).
\end{abstract}

Key words: halophyte, nature conservation, saline habitat, Slovakia, species extinction.

\section{Introduction}

In Slovakia, it was a question whether halophytic vegetation originated as climax associations or developed only after the removal of the native forests but the present literature does not doubt the originality of some alkali habitats in Slovakia (Fehér 2007). The saline habitats enlarged their area after river regulations, drainage of marshes and traditional grazing throughout centuries. The largest area they covered was probably reached in the 19th century. In the 20th century the most alkali habitats were recultivated (creating arable lands etc.). Some fragmented residual saline habitats remained only in lowland areas of SW and SE Slovakia. At present, these habitats are rare, endangered and degraded (missing grazing, ploughing away, hydroamelioration, waste dumps, fertilisation, ruderalisation etc., details in Fehér 2007).

\section{The study area}

In SW Slovakia, the geological ground consists of river sediments and loess. The soils are fertile, mainly alluvial soils, luvisol and chernozyem. The entire area belongs to the European continental climate area of the mild zone with the oceanic air, transforming into the continental one. The average annual temperature is about $9^{\circ} \mathrm{C}$, annual rainfalls aggregate of $540-560 \mathrm{~mm}$. The studied area is classified with the region of Pannonian flora (Pannonicum).

\section{Research methods}

Within the paper we have carried out a floristic, geobotanical and biosozological research of salt habitats of SW Slovakia in the years 2000-2010. The causes of species extinction have been identified, and then quantified by comparative statistical methods (the changes in number of localities, number of species and number of plant communities).

\section{Results and discussion}

The fragments of alkali habitats are small but of different type. Most of them are on solonetz soils, other ones 
seems to be more solonchak steppe type with a higher sand content in the soil. We can find alkali steppe-wood-like habitats (Iža), steppe meadows (the locality Szirányi-tag in Tvrdošovce), dried saline wetlands (Búč), partly desalted habitat with a half-artificial mosaic in development (Pavol in Zlatná na Ostrove). The salt lakes were more common in the past, there is only one of them remained in Tvrdošovce. Some secondary salt lakes had been dug by workers (building railways, brick-clay excavation etc.).

When grazing on primary alkali steppe is finshed, a higher litter accumulation can be observed. Saline habitats tolerate over-grazing quite well. A saline steppe could be changed to secondary steppe by a lower water level (drainage) and then Artemisio santonici-Festucetum pseudovinae changes into Achilleo setaceae-Festucetum pseudovinae Soó (1933) 1947 corr. Borhidi 1996, and Camphorosmetum annuae Rapaics ex Soó 1933 or Puccinellietum limosae Magyar ex Soó 1933 into Artemisio-Festucetum.

The number of known saline habitat localities in Slovakia was 75 in the 18th-20th centuries. The present number is only about $24(32 \%)$ (Fehér 2011, in ed.). It is almost impossible to find new localities (one of them, the locality Balát in Vel'ký Kýr, was mapped in 2010, Fehér \& Fehér Pindešová, in ed.).

According to the Slovak Red Book of Vascular Plants (Čeřovsky et al. 1999; Feráková et al. 2001), the number of quadrate plots $(10 \times 10 \mathrm{~km})$ with occurrence of rare halophytes is decreasing (SW Slovakia/Slovakia): Artemisia santonicum subsp. patens EN 10/11, Atriplex littoralis CR 10/11, Beckmannia eruciformis CR 0/4, Bupleurum tenuissimum EN 7/15, Camphorosma annua CR 9/9, Chenopodium botryoides EX? 6/6, Cirsium brachycephalum EN 6/12, Crypsis aculeata CR 1/1, Galatella cana CR 1/1, Galatella punctata CR 2/4, Glaux maritima EN 0/2, Heleochloa alopecuroides CR 8/15, Heleochloa schoenoides CR 16/22, Iris spuria CR 2/2, Limonium gmelinii subsp. hungaricum CR 1/1, Pholiurus pannonicus CR 6/7, Plantago tenuiflora CR 5/6, Puccinellia limosa EN 12/13, Ranunculus latetiflorus CR 0/7, Ranunculus pedatus EN 2/2, Scorzonera parviflora EN 8/10, Taraxacum bessarabicum NT 6/8, Trifolium angulatum EX? 1/1, Trifolium strictum CR 1/1, Triglochin maritima EN 1/8, Tripolium pannonicum EN 9/11 (data valid in the 90-ies, the new list with quantified localities is in the process of development). Other disappearing halophytes are not included in the Red Book, e.g. Bolboschoenus maritimus (agg.) EN, Festuca pseudovina, Juncus gerardii EN, Schoenoplectus tabernaemontani CR etc., others are (probably) extinct (e.g. Acorellus pannonicus, Peucedanum officinale, Salicornia herbacea, Suaeda maritima). There is only one expanding halophyte, Festuca distans, that spreads along the road-sides because of winter maintenance of driveways by salt.

The halophytic plant communities also disappear. The lists of alkali phytocoenoses published in the past are not valid any more. According to Dítě et al. (2010) the associations Camphorosmetum annuae Rapaics ex Soó 1933, Limonio-Artemisietum santonici (Soó 1927) Ţopa 1939 and Pholiuro pannonici-Plantaginetum tenuiflorae Wendelbg. 1943 are critically endangered. Other ones are close to become classified CR in the near future [Achilleo setaceaeFestucetum pseudovinae Soó (1933) 1947 corr. Borhidi 1996, Artemisio santonici-Festucetum pseudovinae Soó in Máthé 1933 corr. Borhidi 1996]. The coenosis Acorelletum pannonici Soó (1933) Wendelbg. 1943 disappeared recently and also Crypsidetum aculeatae Wenzl 1934 seem to be extinct.

\section{Refernces}

Čeřovský J., Feráková V., Holub J., Maglocký Š. \& Procházka F., (eds), Červená kniha ohrozených a vzácnych druhov rastlín a živočíchov SR a ČR, Vol. 5, Vyššie rastliny [Red Book of endangered and rare species of flora and fauna of the Slovak and Czech Republic, Vol. 5, Vascular plants], Vydavatel'stvo Príroda, Bratislava, 456.

Dítě D., Eliáš P. \& Melečková Z., 2010, Slaniská - zanikajúce refúgiá vzácnej flóry v pol’nohospodárskej krajine [Saline habitats - disapperaing refugia of rare flora in agricultural landscape], [in:] M. Eliášová (ed.), Starostlivost' o biodiverzitu vo vidieckej krajine, SPU, Nitra: 21-26.

Fehér A., 2007, Origin and development of the salt steppes and marshes in SW Slovakia, Flora Pannonica 5: 6794.

Fehér A. \& Fehér Pindešová I., 2011, Floristické poznámky k novoobjavenému slanisku Balát vo Vel'kom Kýri [Remarks to the flora of the saline habitat of Balát discovered recently in Vel'ký Kýr], Bull. Slov. Bot. Spoločn. 33, in ed.

Feráková V., Maglocký Š. \& Marhold K., 2001, Červený zoznam paprad'orastov a semenných rastlín Slovenska [Red list of ferns and flowering plants of Slovakia], Ochrana prírody 20, Suppl.: 48-81. 